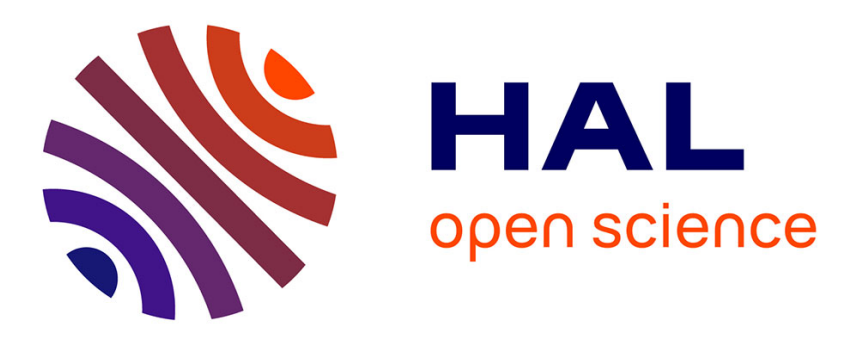

\title{
Alix is involved in caspase 9 activation during calcium-induced apoptosis.
}

Flavie Strappazzon, Sakina Torch, Christine Chatellard-Causse, Anne Petiot, Chantal Thibert, Béatrice Blot, Jean-Marc Verna, Rémy Sadoul

\section{- To cite this version:}

Flavie Strappazzon, Sakina Torch, Christine Chatellard-Causse, Anne Petiot, Chantal Thibert, et al.. Alix is involved in caspase 9 activation during calcium-induced apoptosis.. Biochemical and Biophysical Research Communications, 2010, 397 (1), pp.64-9. 10.1016/j.bbrc.2010.05.062 . inserm00498756

\section{HAL Id: inserm-00498756 https://www.hal.inserm.fr/inserm-00498756}

Submitted on 8 Jul 2010

HAL is a multi-disciplinary open access archive for the deposit and dissemination of scientific research documents, whether they are published or not. The documents may come from teaching and research institutions in France or abroad, or from public or private research centers.
L'archive ouverte pluridisciplinaire HAL, est destinée au dépôt et à la diffusion de documents scientifiques de niveau recherche, publiés ou non, émanant des établissements d'enseignement et de recherche français ou étrangers, des laboratoires publics ou privés. 


\section{Communications}

Elsevier Editorial System(tm) for Biochemical and Biophysical Research

Manuscript Draft

Manuscript Number:

Title: Alix is involved in caspase 9 activation during calcium induced apoptosis.

Article Type: Regular Article

Keywords:

Alix, ALG-2, calcium, caspase, neurons, endoplasmic reticulum, apoptosis

Corresponding Author: Pr. Remy Sadoul,

Corresponding Author's Institution: Grenoble Institut des Neurosciences,

First Author: Flavie Strappazzon

Order of Authors: Flavie Strappazzon; sakina Torch; christine chatellard-causse; anne petiot; chantal thibert; béatrice blot; Jean-Marc Verna; Remy Sadoul 
Equipe 2- Neurodégénérescence et Plasticité

Direction : Pr. Rémy Sadoul

Tel 0456520551

FAX 0456520554

Grenoble May, $7^{\text {th, }} 2010$

Dear Editor

Please find enclosed our manuscript entitled

Alix is involved in caspase 9 activation during calcium induced apoptosis by

F. Strappazzon, S. Torch, C. Chatellard-Causse, A. Petiot, C. Thibert, B. Blot, J.-M. Verna and R. Sadoul, which we would like to submit Biochemical and Biophysical Research Communications

Sustained increase in cytosolic calcium may induce caspase activation and thereby apoptosis. A number of reports demonstrated that caspase 9 is the apical caspase involved in this process. However, the molecular mechanisms leading to caspase 9 activation by calcium remain dubious. Rao and collaborators previously found that the penta-EF hand protein ALG-2 (apoptosis linked gene-2) might be part of an endoplasmic reticulum based complex allowing activation of the caspase. We have previously demonstrated both in vivo and in vitro that a main calcium dependent interactor of ALG-2, called Alix is involved in neuronal death, We therefore tested whether Alix might also take part in apoptosis induced by imbalanced calcium homeostasis. Here, we report that dominant negative mutants of Alix do indeed impair apoptosis induced by thapsigargin treatment of cultured cerebellar neurons and BHK21 cells. Furthermore knock-down of Alix inhibited caspase 9 activation and thereby apoptosis of BHK21 cells treated with thapsigargin. Thus our results define Alix as a crucial mediator of caspase-9 activation following calcium elevation.

This work not only sheds new light on the function of Alix but also paves the way towards a better understanding of caspase 9 activation following imbalanced calcium homeostasis. We hope you will share our enthusiasm over these findings and find this manuscript suitable for publication in BBRC..

Sincerely Yours

Rémy Sadoul

Adresse géographique

Bâtiment Edmond J Safra des Neurosciences, Chemin Fortuné Ferrini, F 38700 La Tronche Adresse postale

Grenoble Institut des Neurosciences - INSERM U836 / Equipe2

Université Joseph Fourier - Site Santé de La Tronche, BP 170, 38042 Grenoble Cedex 9, France 


\section{Alix is involved in caspase 9 activation during calcium induced apoptosis.}

Flavie Strappazzon ${ }^{1,2,3}$, Sakina Torch ${ }^{1,2}$, Christine Chatellard-Causse ${ }^{1,2}$, Anne Petiot ${ }^{1,2}$, Chantal Thibert $^{1,2}$, Béatrice Blot ${ }^{1,2}$, Jean-Marc Verna ${ }^{1,2,4}$, Rémy Sadoul ${ }^{1,2}$ *

1-Inserm, U836, team 2, Grenoble, F-38000 France;

2-Université Joseph Fourier, Grenoble, F-38000 France.

3- present address: Laboratory of Molecular Neuroembryology, IRCCS Fondazione Santa Lucia, Via del Fosso di Fiorano 64/65, 00143 Rome, Italy

4-present address: Service des Ressources Humaines, Délégation Alpes, CNRS - BP 166, 38042 Grenoble, France

*Correspondence should be addressed to Rémy Sadoul, Grenoble Institut des Neurosciences,

Bâtiment Edmond J. Safra des Neurosciences, chemin Fortuné Ferrini, Site Santé, 38706 La

Tronche cédex, France. Tel: +3347656520548. E-mail: remy.sadoul@ujf-grenoble.fr

Running Title: Alix in calcium-induced cell death 


\section{ABSTRACT}

The cytoplasmic protein Alix/AIP1 (ALG-2 interacting protein-X) is involved in cell death through mechanisms which remain unclear but require its binding partner ALG-2 (ApoptosisLinked-Gene- 2). The latter was defined as a regulator of calcium-induced apoptosis following endoplasmic reticulum (ER) stress. We show here that Alix is also a critical component of caspase 9 activation and apoptosis triggered by calcium. Indeed, expression of Alix dominant negative mutants or downregulation of Alix afford significant protection against cytosolic calcium elevation following thapsigargin $(\mathrm{Tg})$ treatment. The function of Alix in this paradigm requires its interaction with ALG-2. In addition, we demonstrate that caspase 9 activation is necessary for apoptosis induced by $\mathrm{Tg}$ and that this activation is impaired by knocking down Alix. Altogether, our findings identify, for the first time, Alix as a crucial mediator of $\mathrm{Ca}^{2+}$ induced caspase 9 activation.

1

${ }^{1}$ Abbreviations

ALG-2: Apoptosis Linked Gene-2; Alix: ALG-2 Interacting protein X; Apaf-1: Apototic protease activating factor-1; BHK: Baby hamster kidney; DIV: days in vitro; ER: Endoplasmic reticulum; RFP: Red Fluorescent Protein; Tg: Thapsigargin; 


\section{INTRODUCTION}

Calcium plays a central role in regulating a variety of cellular responses, notably in neurons. In particular, it is now well established that alteration in intracellular calcium homeostasis is a common feature of many apoptotic processes, which are associated with local elevations of cytosolic $\mathrm{Ca}^{2+}$ released from endoplasmic reticulum (ER) stores [1,2,3,4,5]. Although cytosolic $\mathrm{Ca}^{2+}$ elevation induces caspase 9 activation as a necessary step for apoptosis, the way of activation of the caspase remains dubious. In particular, it is still unclear whether caspase 9 activation requires Apaf- 1 or occurs in a separate ER based complex $[6,7,8]$. Using Apaf-1 -/- cells, Rao et al defined the apopotosis-linked gene-2 (ALG-2), a calcium-binding protein belonging to the penta-EF hand protein family, as a regulator of ER stress-induced death involving $\mathrm{Ca}^{2+}$ [8]. Indeed, knock-down of ALG-2 reduced cell death due to thapsigargin (Tg), which elevates cytosolic calcium by blocking the ER $\mathrm{Ca}^{2+}$ ATPase. They went on to suggest that ALG-2 is part of a high molecular weight complex containing caspases 9 and 12 and that knocking down ALG-2 inhibits Tg induced caspase-9 activation.

$\mathrm{Ca}^{2+}$ binding to ALG-2 induces a conformational change which allows it to interact with several proteins $[9,10]$, among which the multifunctional adaptor protein Alix/AIP1 [11,12]. Alix is a cytosolic protein which interacts with proteins involved in deforming membranes during various processes including endocytosis, endosomal sorting, virus budding and cytokinesis $[13,14]$. Up-regulation of Alix expression in vivo correlates with calcium induced cell death, as observed in degenerating neurons of the rat hippocampus undergoing epileptic seizures [15]. We also found that over-expression of the full length protein (Alix-wt) in cultured neurons was sufficient to activate caspases and thereby apoptosis. In contrast expression of the C-terminal half of the protein encompassing the ALG-2 binding site blocked neuronal death both in vivo and in 
vitro $[16,17]$. The pro- and anti-apoptotic functions of Alix-wt and Alix-CT respectively were tightly dependent on their capacity to bind to ALG-2. Expression of Alix lacking its ALG-2 binding site could block naturally occurring death of motoneurons during development of the chick embryo [18,19]. Given the fact that ALG-2 needs to bind $\mathrm{Ca}^{2}$ in order to interact with Alix, these observations suggest that ALG-2 and Alix cooperate in transducing $\mathrm{Ca}^{2+}$-regulated signals during cell death. Here we report that knock-down of Alix protects cells from Tg-induced cell death which is mediated by caspase 9. Furthermore, we show that Alix expression is required for caspase 9 activation induced by calcium elevation. These results suggest that Alix and ALG-2 act upstream of caspase 9 activation following cytosolic calcium elevation.

\section{MATERIAL AND METHODS}

\section{Constructs and antibodies}

Polyclonal anti-Alix was previously described [16], rabbit anti-Flag (Sigma), monoclonal antiHA (Cell Signaling), monoclonal anti-actin (Chemicon), alexa-488 conjugated goat anti-rabbit and alexa-488 conjugated goat anti mouse (Molecular Probes), peroxidase-conjugated goat antimouse and peroxidase goat anti-rabbit (Jackson). Alix expression plasmids have been described previously [20]. pcDNA3 vectors coding for dominant-negative mutants of procaspase-8 (C360A) and -9 mutants (C287A) were a kind gift of P. Mehlen (Lyon).

\section{Cell cultures}

Primary cultures of cerebellar granule cells (CGN) were prepared from 6-day-old S/IOPS NMRI mice (Charles River Laboratories), as described previously [16]. Dissociated neurons were plated in Dulbecco's modified Eagle's medium (DMEM, Invitrogen) containing $25 \mathrm{mM} \mathrm{KCl}$ (K25 medium) supplemented with $10 \%$ fetal bovine serum. After 4 DIV, the medium was replaced 
with serum-free K25. 24h later, thapsigargin (Invitrogen) (200 nM in $0.01 \%$ DMSO) or DMSO alone were added to K25 medium. Baby Hamster Kidney cells (BHK-21) were used as described previously [21]. Cells were treated with $1 \mu \mathrm{M} \mathrm{Tg} 24 \mathrm{~h}$ after plating.

\section{Cell transfections}

Transient transfection of cultured CGN was performed using the calcium phosphate coprecipitation method as previously described [16]. BHK-21 cells were grown at $37^{\circ} \mathrm{C}$ in Glasgow MEM (GMEM) supplemented with 5\% fetal calf serum. Transient transfections of BHK-21 cells were performed using JetPEI (PolyPlus Transfection).

\section{Establishment of an Alix-deficient BHK-21 cell line}

An shRNA was cloned downstream of the human H1 promoter in the pSuperGFP vector (Oligoengine, Seattle, WA, USA). Forward and reverse sequences for the Alix shRNA construct were: 5'GATCCCCGCCGCTGGTGAAGTTCATCTTCAAGAGAGATGAACTTCACCAGCG GCTTTTTGGAAA-3'

and 5’AGCTTTTCCAAAAAGCCGCTGGTGAAGTTCATCTCTCTTGAAGATGAACTTCACCA GCGGCGGG-3', respectively. The synthetic oligonucleotides were synthesised by Invitrogen. The annealed oligonucleotides were ligated into the BglII-HindIII site of the pSuperGFP vector. BHK-21 cells were transfected with pSuper- shAlix or pSuper vectors as control by using JetSi transfection (Polyplus tranfection). Cells were selected by adding G418 $(800 \mu \mathrm{g} / \mathrm{ml})$ to the culture medium. After 15 days, clones were isolated and screened by Western blot analysis for the best reduction in Alix expression. Permanent cell lines (pSuper/shAlix and control were maintained with G418 $(800 \mu \mathrm{g} / \mathrm{ml})$. 


\section{Determination of cell viability}

MTT assay: the tetrazolium salt MTT [3-(4,5-dimethyl-2-thiazolyl)-2-5diphenyl-2H tetrazolium bromide] (Sigma) was added to cell cultures $(1 \mathrm{mg} / \mathrm{ml})$ and incubated for $30 \mathrm{~min}$ at $37^{\circ} \mathrm{C}$. Cells were then lysed in DMSO. Formazan production by living cells was assessed by measuring absorbance at $540 \mathrm{~nm}$.

Hoechst staining: cultures were fixed in $4 \%$ paraformaldehyde in PBS for 20 min at $4{ }^{\circ} \mathrm{C}$ and stained with the bisbenzimide (Hoechst 33342 (Sigma); $4 \mu \mathrm{g} / \mathrm{ml}$;) in PBS for 20 min at room temperature. Cells were washed three times with PBS, mounted in Mowiol (Calbiochem) and observed under an Axiovert microscope (Zeiss) connected to a CDD camera. For each condition, random images were captured and analyzed. Cell viability was then scored on the basis of nuclear morphology: cells containing condensed or fragmented nuclei were counted as dying or dead cells.

\section{Determination of capase 9 activation in cells.}

Caspase 9 Detection kit (Calbiochem) uses the fluorescent marker red LEHD-fmk which enters living cells and binds irreversibly to activated caspase 9. After $24 \mathrm{hr}$ treatment with $1 \mu \mathrm{M} \mathrm{Tg}$ or vehicle (DMSO), cells were incubated for $1 \mathrm{~h}$ at $37^{\circ} \mathrm{C}$ with the fluorescent marker according to the supplier's instructions and observed under an Axiovert microscope (Zeiss).

\section{Immunofluorescence}

Cells were fixed in $4 \%$ paraformaldehyde in PBS for $10 \mathrm{~min}$ at $37^{\circ} \mathrm{C}$. After permeabilization and blocking with 3\% goat pre-immune serum (Invitrogen), cells were incubated at room temperature with primary antibodies (monoclonal anti HA : 1/100, polyclonal anti-Flag : 1/500) then with Alexa Fluor-conjugated secondary anti-mouse antibody (1/1000) or anti-rabbit antibody (1/1000) (Invitrogen). Cells were rinsed with PBS, and stained with Hoechst 33342 before examination. 


\section{Western blot analysis}

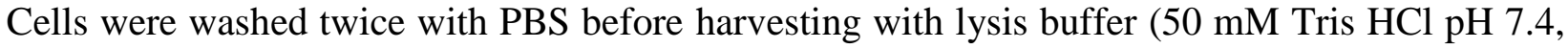
$150 \mathrm{mM} \mathrm{NaCl}, 0.5 \%$ DOC (sodium deoxycholate), 1\% NP40, $0.1 \%$ SDS (Sodium Dodecyl Sulfate), $1 \mathrm{mM} \mathrm{Na} \mathrm{VO}_{4}, 50 \mathrm{mM} \mathrm{NaF}, 10 \mathrm{mM} \beta$-glycerophosphate and $2 \mathrm{X}$ protease inhibitor cocktail (Complete ${ }^{\mathrm{TM}}$, Boehringer). Cell extracts were centrifuged at $15,000 \mathrm{~g}$ for $15 \mathrm{~min}$ at $4^{\circ} \mathrm{C}$ and $20 \mu \mathrm{g}$ protein was separated by SDS-PAGE and transferred onto nylon membranes (Immobilon-P, Millipore). After incubation with the membranes primary antibodies were revealed using peroxidase-coupled secondary antibodies and the SuperSignal detection method (Pierce).

\section{RESULTS}

\section{1- Alix C-terminal half protects BHK-21 cells and cerebellar neurons from thapsigargin- induced cytotoxicity.}

We first used BHK-21 cells to analyze the effect of the C-terminal half of Alix (Alix-CT) on apoptosis following a $\mathrm{Ca}^{2+}$ increase due to $\mathrm{Tg}$ treatment. $24 \mathrm{~h}$ after transfection, BHK-21 cells were treated with $1 \mu \mathrm{M} \mathrm{Tg}$ and viability estimated after a further $24 \mathrm{~h}$ culture period. $60 \%$ of control RFP-expressing cells exhibited altered nuclear morphology indicative of apoptosis whereas $15 \%$ were dead or dying in untreated control cultures (Figure 1a). In contrast, only 30\% of Alix-CT-expressing cells died following the same treatment. Remarkably, Alix-CT deleted of its ALG-2-binding domain (Alix-CT $\triangle$ ALG-2) did not afford any protective effect against $\mathrm{Tg}$ induced apoptosis (Figure 1a).

Similar experiments using cerebellar granule neurons (CGN) gave comparable results. Indeed, while a $24 \mathrm{~h}$ incubation with $200 \mathrm{nM} \mathrm{Tg}$ increased death of RFP transfected CGN by 36 
$\%$, the number of Alix-CT-expressing neurons showing a condensed or fragmented nucleus did not significantly differ from that of untreated cultures (Figure 1b). Deletion of the ALG-2 binding site on Alix-CT abrogated its capacity to rescue neurons. Our findings indicate that expression of a dominant negative form of Alix counteracts the deleterious effect of $\mathrm{Tg}$ in a way which depends on its capacity to interact with ALG-2.

\section{2- Alix depletion reduces thapsigargin-induced cell death.}

To reinforce our suggestion of a possible role of Alix in mediating ER stress apoptosis, we established a BHK-21 cell line in which we down regulated Alix expression using a pSuper vector coding for a short hairpin RNA against Alix (Sh Alix). As illustrated in Figure 2a, Alix content was reduced by at least $90 \%$ in cells stably expressing Sh Alix compared to control cells expressing an empty P-Super (Sh control). Exposure to $1 \mu \mathrm{M} \mathrm{Tg}$ did not significantly alter Alix expression in $S h$ control or $S h$ Alix cells (Figure 2a). Using the MTT assay, we observed a timedependent reduction in metabolic activity of $S h$ control cells following Tg treatment reaching 70 $\%$ at $72 \mathrm{~h}$ (Figure 2b). In contrast, after an initial limited decline, MTT metabolism remained constant over until the end of the experiment in Sh Alix cells. These findings suggest that Alixdepleted cells are less sensitive to Tg cytotoxity. To confirm this, cell viability was estimated using Hoechst nuclear staining $24 \mathrm{~h}$ after addition of Tg. After Tg treatment about $55 \%$ of $S h$ control cells exhibited condensed or fragmented nuclei, while only $15 \%$ of Sh Alix cells showed these apoptotic features (Figure 2c). Therefore, reducing Alix expression greatly improves the survival of BHK-21 cells exposed to $\mathrm{Tg}$.

To strengthen our finding, we restored Alix expression in Sh Alix BHK-21 cells using an expression vector coding for the protein (Figure 2c Upper panel). Even though, Alix 
overexpression did not affect the sensitivity of $S h$ control cells towards $\mathrm{Tg}$, it almost completely restored Tg-induced death in $S h$ Alix cells (Figure 2c). In contrast, RFP expression did not influence viability in either $S h$ control or Sh Alix cells. This observation, together with the fact that Alix $\triangle \mathrm{ALG}-2$ did not significantly restore Tg-induced cell death indicates that Alix mediates apoptosis following cytosolic $\mathrm{Ca}^{2+}$ elevation and that this activity requires its capacity to bind to ALG-2.

\section{3- Caspase 9 activation is required for $\mathbf{T g}$-induced apoptosis.}

Since Alix overexpression is sufficient to activate caspases in CGN [16], we hypothesized that Alix downregulation might affect activation of apical caspases following $\mathrm{Tg}$ treatment. Because some reports involved caspase 8 [22] and caspase 9 [7,23] in ER stress, we first determined which of these two caspases initiates Tg-induced death in BHK-21 cells. For this we tested the effects on cell survival of catalytically dead mutants (DN-caspases) of caspases 8 and 9 which inhibit activation of their relevant endogenous counterparts. $24 \mathrm{~h}$ after transfection, BHK21 cells were treated with $1 \mu \mathrm{M} \mathrm{Tg}$ and further grown for $24 \mathrm{~h}$ (Figure 3a). This treatment robustly increased the number of apoptotic cells among control cultures expressing RFP. Tginduced apoptosis was significantly reduced by DN-caspase 9 expression as did the pan-caspase inhibitor BAF. In contrast expression of DN-caspase 8 did not afford protection but even significantly sensitized cells to $\mathrm{Tg}$. Thus, activation of caspase 9 seems to be necessary for BHK21 apoptosis induced byTg.

\section{4- Alix is involved in caspase 9 activation required for thapsigargin-induced apoptosis.}

We then tested the relationship between Alix and caspase 9 activation following $\mathrm{Tg}$. 
Using a Caspase 9 detection kit, activated caspase 9 could not be detected in either $S h$ control or Sh Alix cells (Figure 3b). However, following a $24 \mathrm{~h}$ exposure to Tg, caspase 9 activation could be detected in $30 \%$ of Sh control cells. Most of these cells displayed condensed or fragmented nuclei typical of apoptosis. In sharp contrast, the number of cells containing activated-caspase 9 did not increase significantly after Tg treatment in cells in which Alix was knocked down (Figure 3c). This demonstrates that Alix is required for caspase 9 activation following Tg treatment.

\section{DISCUSSION}

Alix controls some aspects of cell death, particularly neuronal apoptosis induced by various stimuli $[15,16,17,24]$. Here, we provide the first evidence for a role of Alix in mediating caspase 9 activation and apoptosis involving alteration in $\mathrm{Ca}^{2+}$ homeostasis. Expression of a dominant-negative form of Alix (Alix-CT) protects CGN and BHK-21 cells against apoptosis induced by $\mathrm{Tg}$, which blocks the sarcoendoplasmic reticulum $\mathrm{Ca}^{2+}$-ATPase (SERCA). Deletion of the ALG-2 binding site on Alix-CT abolished the capacity of the mutant to block cell death. Consistent with this, Alix knock down in BHK-21 cells protected these cells against Tg whereas complementation with wt Alix (wild-type Alix) restored their susceptibility to Tg in a way depending on its capacity to bind ALG-2. Finally we also show that Alix is necessary for caspase 9 activation, a process necessary for induction of apoptosis induced by $\mathrm{Tg}$.

Our finding that, in BHK cells, caspase 9 is instrumental for apoptosis induced by cytosolic elevation is in good agreement with several reports showing that cells derived from caspase 9 knock-out animals or in which caspase 9 activation was blocked, are protected against death induced by alteration in ER calcium homeostasis $[6,7,8]$. More disputed is the way of activation of caspase 9, which was demonstrated to be both dependent and independent of the 
intrinsic/Apaf-1 pathway [6,8]. Rao et al demonstrated that ALG-2 co-immunoprecipitates with vectorially expressed caspases 9 and 12. They also showed that knock-down of ALG-2 inhibits activation of procaspase 9 and suggested that activation by Tg stress features an Apaf-1independent pathway that requires, among others, ATP, calcium, ALG-2, caspase 9, caspase 12 and additional factors present in microsomes [8]. Several studies have now shown that, in various situations and several types of cells [25], caspase 12 is not critical for the ER stress-induced apoptotic cascade $[6,22,23,26]$. Our present results demonstrate that, like ALG-2, Alix expression is necessary for caspase- 9 activation induced by $\mathrm{Tg}$.

Another link between the ER and ALG-2 had been demonstrated by Draeby et al [27] who reported that ALG-2 interacts with the ER-localized scotin protein which is a proapoptoticp53-inducible protein. Noteworthy is that deletion of the PRD C-terminal region of scotin containing the ALG-2 binding site, abolished the ER localization and proapoptotic function of the protein. Furthermore, ALG-2 is temporarily and $\mathrm{Ca}^{2+}$-dependently recruited by Sec31 of Cop-II at ER exit sites [28,29,30]. Alix also translocates to ER exit sites in response to a rise in cytoplasmic $\mathrm{Ca}^{2+}$ suggesting a possible function of the protein in this compartment [30]. In line with this, we have previously reported that Alix-CT expressed in HEK-293 cells concentrates on tubular vesicular structures stained with an antibody recognizing ER resident proteins bearing KDEL [20]. Thus Alix and ALG-2 localization is compatible with a scenario in which changes in ER $\mathrm{Ca}^{2+}$ homeostasis induce the $\mathrm{Ca}^{2+}$-dependent recruitment by ALG-2 of Alix and additional proteins required for the building of a platform allowing activation of caspase 9. 


\section{FIGURE LEGENDS}

Figure 1: Ectopic expression of the C-terminal half of Alix delays cell death of BHK-21 cells and CGN induced by an ER stress.

BHK-21 cells grown for $24 \mathrm{~h}$ (a) or cerebellar granule neurons (CGN) cultured for 4 days (b) were transfected with vectors encoding either Flag-Alix-CT, Flag-Alix-CTAALG-2 or RFP. One day later, cells were treated with $\operatorname{Tg}(1 \mu \mathrm{M}$ (a) $200 \mathrm{nM}$ (b)) or vehicle (0.01\% DMSO) for $24 \mathrm{~h}$. Transfected cells were revealed using an anti-Flag antibody and cells with condensed/fragmented nuclei were scored as pyknotic. Results are expressed as the percentage of transfected cells displaying pyknotic nuclei. Values are given as a percentage ( \pm S.D.) of cell death and statistical analysis was performed by analysis of variance (One-way ANOVA followed by Scheffe's posthoc test). ${ }^{*} P<0.05$ versus RFP control.

\section{Figure 2: Reduction of Alix expression protects BHK-21 cells from Tg cytotoxicity}

(a) Western-blot analysis of Alix expression in $S h$ control or $S h$ Alix BHK-21 cells with or without $\mathrm{Tg}$ for $24 \mathrm{~h}$.

(b) Sh control or Sh Alix BHK-21 cells were treated with $1 \mu \mathrm{M}$ Tg and the percentage of viable cells was estimated at various time intervals using the MTT assay. Results are expressed as a percentage of the metabolic activity at $\mathrm{t}=0$ in Tg-treated cultures relative to DMSO-treated control cultures. Each point represents the mean \pm S.D. of triplicate wells from three independent experiments.

(c) Alix expression restores sensitivity of Sh Alix cells to Tg cytotoxicity.

Sh control or Sh Alix BHK-21 cells were transfected with a vector coding either for Flag-Alix, Flag-Alix $\Delta$ ALG-2 or RFP. Upper panel: WB analysis of cell extracts of $S h$ control and $S h$ Alix 
cells using an anti-Flag antibody demonstrating expression of Alix and Alix $\Delta$ ALG-2 in transfected cells. Bottom panel: Twenty-four hours after transfection, cells were exposed to $\mathrm{Tg}(1$ $\mu \mathrm{M})$ during $24 \mathrm{~h}$ and then immunostained with an anti-Flag antibody. Cells were counted in 10 random fields in two or three different wells and condensed/fragmented nuclei were scored as pyknotic. Results are expressed as the percentage of transfected cells displaying a pyknotic nucleus. Data are means $\pm \mathrm{SD}$ of three independent experiments. Statistical analysis was performed by analysis of variance (One-way ANOVA followed by Scheffe's post-hoc test). ${ }^{*} P<$ 0.05 versus RFP-overexpressing Sh Alix cells.

Figure 3: Reduction of Alix expression impedes caspase 9 activation following Tg treatment in BHK-21 cells.

(a) Expression of DN-caspase 9 protects cells from Tg-induced apoptosis.

BHK-21 cells were transfected with vectors coding for RFP or dominant-negative forms of either caspase 8-HA or caspase 9-HA. $24 \mathrm{~h}$ later, cells were treated with $1 \mu \mathrm{M} \mathrm{Tg}, 24 \mathrm{~h}$. RFP transfected cells were treated or not with $100 \mu \mathrm{M}$ pan-caspase inhibitor BAF (Boc-aspartyl (OMe)-fluorymethylketone ; Biorad). Cells were then immunostained using a monoclonal antiHA antibody and nuclei stained with Hoechst. 10 random fields from two or three different wells were counted and condensed/fragmented nuclei were scored as pyknotic. Results are expressed as the percentage of transfected cells displaying pyknotic nuclei. Data represent means \pm SD of three independent experiments. Statistical analysis was performed by analysis of variance (Oneway ANOVA followed by Scheffe's post-hoc test). ${ }^{*} P<0.05$ versus DN-caspase 8 overexpressing BHK-21 cells (treated with DMSO).

(b,c) Caspase 9 activation following Tg treatment requires Alix expression. 
Sh control or Sh Alix BHK-21 cells were treated with $1 \mu \mathrm{M}$ Tg or with DMSO vehicle. After 24 h cells were labelled for activated caspase 9 (red-LETD-fmk) and stained with Hoechst. b: representative fields. Arrows indicate cells with pyknotic nuclei displaying activated caspase 9. c: quantification of cells displaying activated caspase 9. Results are expressed as the percentage of cells labeled with red LETD-fmk. Data represent means \pm SD of three independent experiments. *: $\mathrm{p}=0.0002$ using Student's t test. No significant difference in the percentage of cells displaying activated caspases 9 could be observed between shAlix cells with or without $\mathrm{Tg}$ $(\mathrm{p}=0.14)$

This study was partly supported by the Institut National de la Santé et de la Recherche Médicale (Inserm), the Université Joseph Fourier and by funds from the Association Française contre les Myopathies, the Association pour la recherche sur le cancer (ARC), the Association pour la Recherche sur la Sclérose Latérale Amyotrophique (ARS) and the Région Rhône-Alpes. F. Strappazzon is the recipient of a grant from the Ministère de l'Education Nationale, de l'Enseignement Supérieur et de la Recherche. We gratefully acknowledge P. Mehlen for caspase contructs, F. J. Hemming for revising the English manuscript, A.L. Mahul and S. Fraboulet for valuable suggestions throughout this work. 


\section{REFERENCES}

[1] M.J. Berridge, M.D. Bootman, P. Lipp, Calcium--a life and death signal., Nature 1998: 395 (1998) 645-648.

[2] M.J. Berridge, P. Lipp, M.D. Bootman, Signal transduction. The calcium entry pas de deux, Science 287 (2000) 1604-1605.

[3] L.K. Nutt, A. Pataer, J. Pahler, B. Fang, J. Roth, D.J. McConkey, S.G. Swisher, Bax and Bak promote apoptosis by modulating endoplasmic reticular and mitochondrial $\mathrm{Ca} 2+$ stores, $\mathrm{J}$ Biol Chem 277 (2002) 9219-9225.

[4] B. Tombal, S.R. Denmeade, J.M. Gillis, J.T. Isaacs, A supramicromolar elevation of intracellular free calcium $([\mathrm{Ca}(2+)](\mathrm{i}))$ is consistently required to induce the execution phase of apoptosis, Cell Death Differ 9 (2002) 561-573.

[5] R. Rizzuto, P. Pinton, D. Ferrari, M. Chami, G. Szabadkai, P.J. Magalhaes, F. Di Virgilio, T. Pozzan, Calcium and apoptosis: facts and hypotheses, Oncogene 22 (2003) 8619-8627.

[6] F. Di Sano, E. Ferraro, R. Tufi, T. Achsel, M. Piacentini, F. Cecconi, Endoplasmic reticulum stress induces apoptosis by an apoptosome-dependent but caspase 12-independent mechanism, J Biol Chem 281 (2006) 2693-2700.

[7] A. Masud, A. Mohapatra, S.A. Lakhani, A. Ferrandino, R. Hakem, R.A. Flavell, Endoplasmic reticulum stress-induced death of mouse embryonic fibroblasts requires the intrinsic pathway of apoptosis, J Biol Chem 282 (2007) 14132-14139.

[8] R.V. Rao, K.S. Poksay, S. Castro-Obregon, B. Schilling, R.H. Row, G. del Rio, B.W. Gibson, H.M. Ellerby, D.E. Bredesen, Molecular components of a cell death pathway activated by endoplasmic reticulum stress, J Biol Chem 279 (2004) 177-187.

[9] H. Suzuki, M. Kawasaki, T. Inuzuka, M. Okumura, T. Kakiuchi, H. Shibata, S. Wakatsuki, M. Maki, Structural basis for Ca2+-dependent formation of ALG-2/Alix peptide complex: Ca2+/EF3-driven arginine switch mechanism, Structure 16 (2008) 1562-1573.

[10] K. Katoh, H. Shibata, H. Suzuki, A. Nara, K. Ishidoh, E. Kominami, T. Yoshimori, M. Maki, The ALG-2-interacting protein Alix associates with CHMP4b, a human homologue of yeast Snf7 that is involved in multivesicular body sorting, J Biol Chem 278 (2003) 39104-39113.

[11] M. Missotten, A. Nichols, K. Rieger, R. Sadoul, Alix, a novel mouse protein undergoing calcium-dependent interaction with the apoptosis-linked-gene 2 (ALG-2) protein, Cell Death Differ 6 (1999) 124-129.

[12] P. Vito, L. Pellegrini, C. Guiet, L. D'Adamio, Cloning of AIP1, a novel protein that associates with the apoptosis-linked gene ALG-2 in a Ca2+-dependent reaction, J Biol Chem 274 (1999) 1533-1540.

[13] R. Sadoul, Do Alix and ALG-2 really control endosomes for better or for worse, Bio. Cell 98 (2006) 69-77.

[14] G. Odorizzi, The multiple personalities of Alix, J Cell Sci 119 (2006) 3025-3032.

[15] F.J. Hemming, S. Fraboulet, B. Blot, R. Sadoul, Early increase of apoptosis-linked gene-2 interacting protein $\mathrm{X}$ in areas of kainate-induced neurodegeneration, Neuroscience 123 (2004) 887-895.

[16] Y. Trioulier, S. Torch, B. Blot, N. Cristina, C. Chatellard-Causse, J.M. Verna, R. Sadoul, Alix, a protein regulating endosomal trafficking, is involved in neuronal death, $\mathrm{J}$ Biol Chem 279 (2004) 2046-2052. 
[17] A.L. Mahul-Mellier, F.J. Hemming, B. Blot, S. Fraboulet, R. Sadoul, Alix, making a link between apoptosis-linked gene-2, the endosomal sorting complexes required for transport, and neuronal death in vivo, J Neurosci 26 (2006) 542-549.

[18] A.L. Mahul-Mellier, F. Strappazzon, A. Petiot, C. Chatellard-Causse, S. Torch, B. Blot, K. Freeman, L. Kuhn, J. Garin, J.M. Verna, S. Fraboulet, R. Sadoul, F.J. Hemming, Alix and ALG-2 are involved in tumor necrosis factor receptor 1-induced cell death, J Biol Chem 283 (2008) 34954-34965.

[19] A.L. Mahul-Mellier, F. Strappazzon, C. Chatellard-Causse, B. Blot, D. Beal, S. Torch, F. Hemming, A. Petiot, J.M. Verna, S. Fraboulet, R. Sadoul, Alix and ALG-2 make a link between endosomes and neuronal death, Biochem Soc Trans 37 (2009) 200-203.

[20] C. Chatellard-Causse, B. Blot, N. Cristina, S. Torch, M. Missotten, R. Sadoul, Alix (ALG-2interacting protein $\mathrm{X}$ ), a protein involved in apoptosis, binds to endophilins and induces cytoplasmic vacuolization, J Biol Chem 277 (2002) 29108-29115.

[21] T. Tuomikoski, M.A. Felix, M. Doree, J. Gruenberg, Inhibition of endocytic vesicle fusion in vitro by the cell-cycle control protein kinase cdc2, Nature 342 (1989) 942-945.

[22] A. Jimbo, E. Fujita, Y. Kouroku, J. Ohnishi, N. Inohara, K. Kuida, K. Sakamaki, S. Yonehara, T. Momoi, ER stress induces caspase-8 activation, stimulating cytochrome c release and caspase-9 activation, Exp Cell Res 283 (2003) 156-166.

[23] E.A. Obeng, L.H. Boise, Caspase-12 and caspase-4 are not required for caspase-dependent endoplasmic reticulum stress-induced apoptosis, J Biol Chem 280 (2005) 29578-29587.

[24] D. Blum, F.J. Hemming, M.C. Galas, S. Torch, L. Cuvelier, S.N. Schiffmann, R. Sadoul, Increased Alix (apoptosis-linked gene-2 interacting protein X) immunoreactivity in the degenerating striatum of rats chronically treated by 3-nitropropionic acid, Neurosci Lett 368 (2004) 309-313.

[25] Y. Kosuge, T. Sakikubo, K. Ishige, Y. Ito, Comparative study of endoplasmic reticulum stress-induced neuronal death in rat cultured hippocampal and cerebellar granule neurons, Neurochem Int 49 (2006) 285-293.

[26] H. Shiraishi, H. Okamoto, A. Yoshimura, H. Yoshida, ER stress-induced apoptosis and caspase-12 activation occurs downstream of mitochondrial apoptosis involving Apaf-1, J Cell Sci 119 (2006) 3958-3966.

[27] I. Draeby, Y.L. Woods, J.M. la Cour, J. Mollerup, J.C. Bourdon, M.W. Berchtold, The calcium binding protein ALG-2 binds and stabilizes Scotin, a p53-inducible gene product localized at the endoplasmic reticulum membrane, Arch Biochem Biophys 467 (2007) 8794.

[28] J.M. la Cour, J. Mollerup, M.W. Berchtold, ALG-2 oscillates in subcellular localization, unitemporally with calcium oscillations, Biochem Biophys Res Commun 353 (2007) 1063-1067.

[29] H. Shibata, H. Suzuki, H. Yoshida, M. Maki, ALG-2 directly binds Sec31A and localizes at endoplasmic reticulum exit sites in a Ca2+-dependent manner, Biochem Biophys Res Commun 353 (2007) 756-763.

[30] A. Yamasaki, K. Tani, A. Yamamoto, N. Kitamura, M. Komada, The Ca2+-binding protein ALG-2 is recruited to endoplasmic reticulum exit sites by Sec31 A and stabilizes the localization of Sec31A, Mol Biol Cell 17 (2006) 4876-4887. 
Figure 1

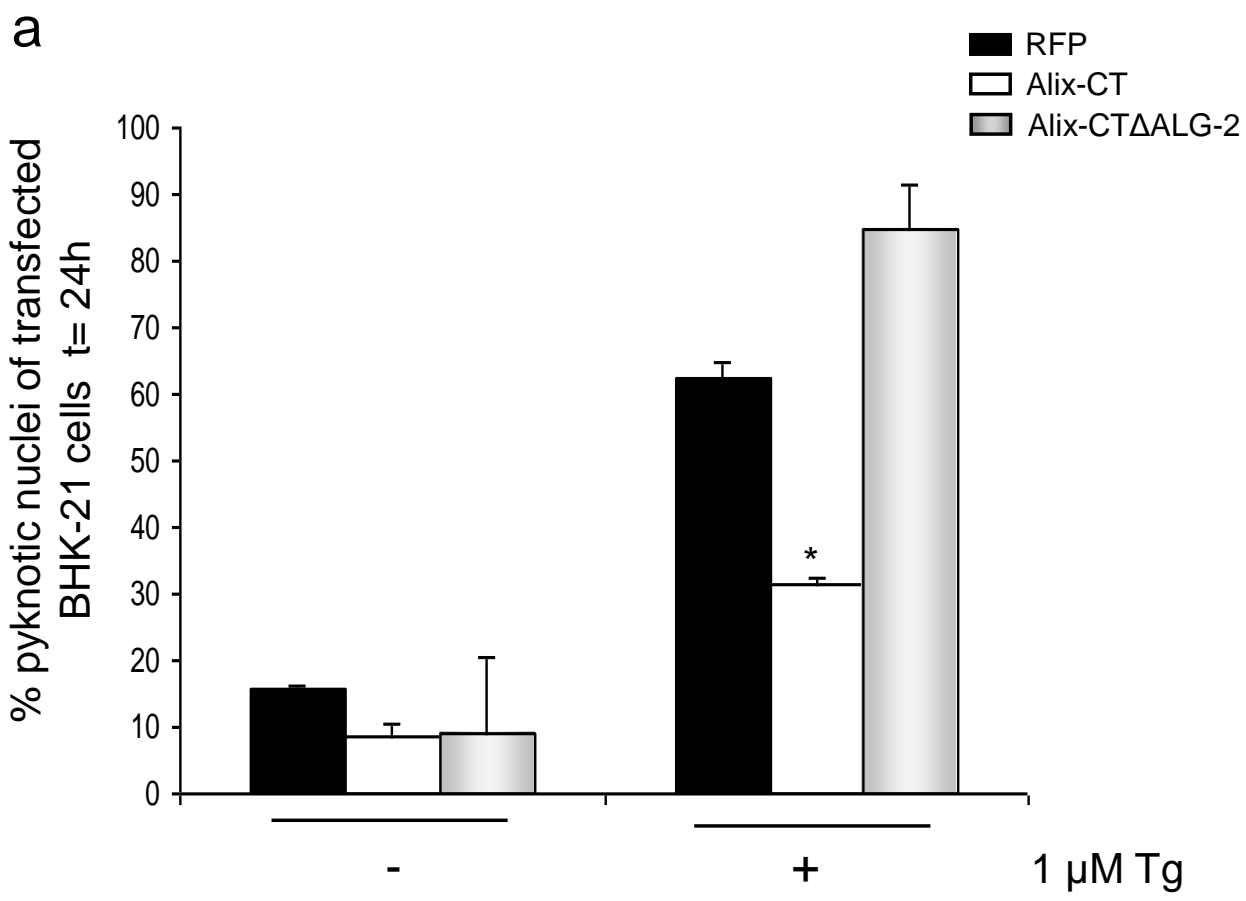

b

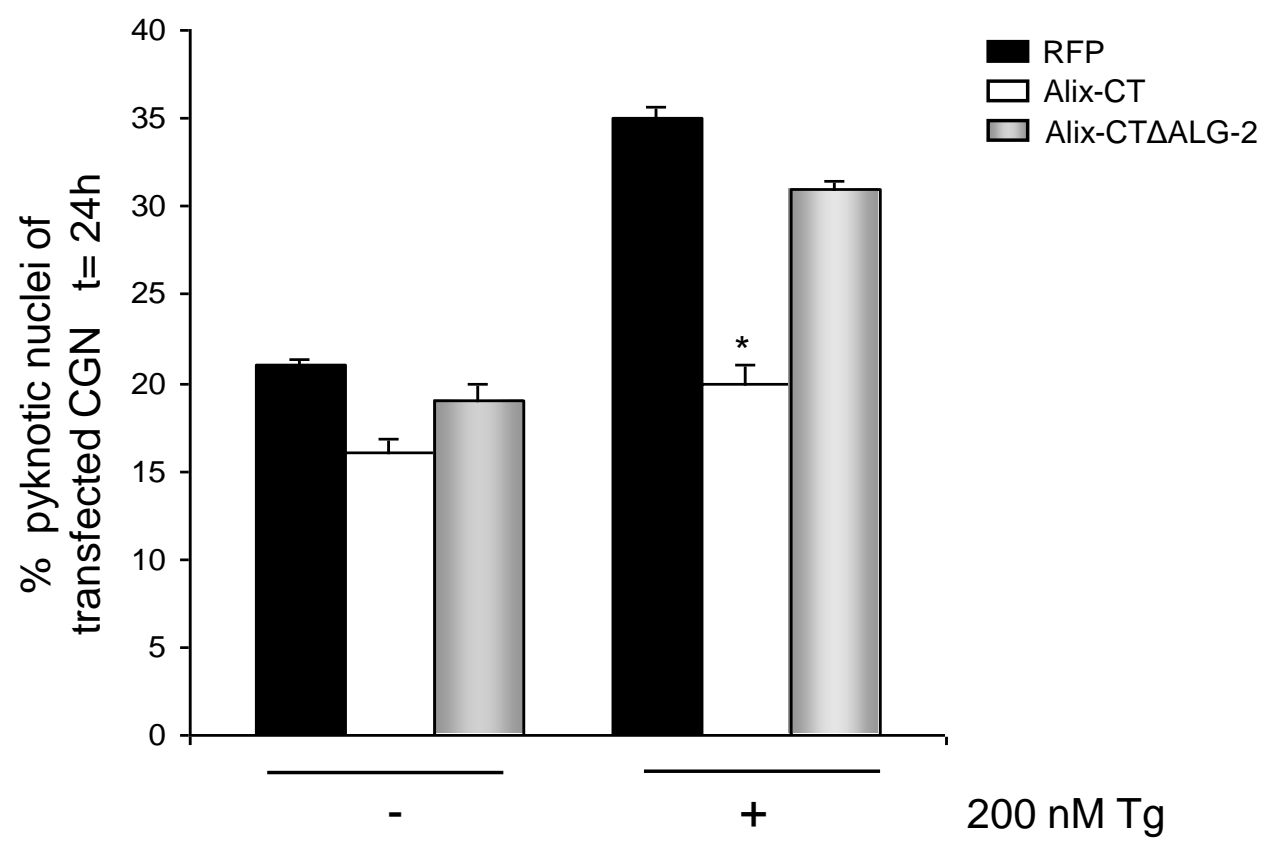


Figure 2

a
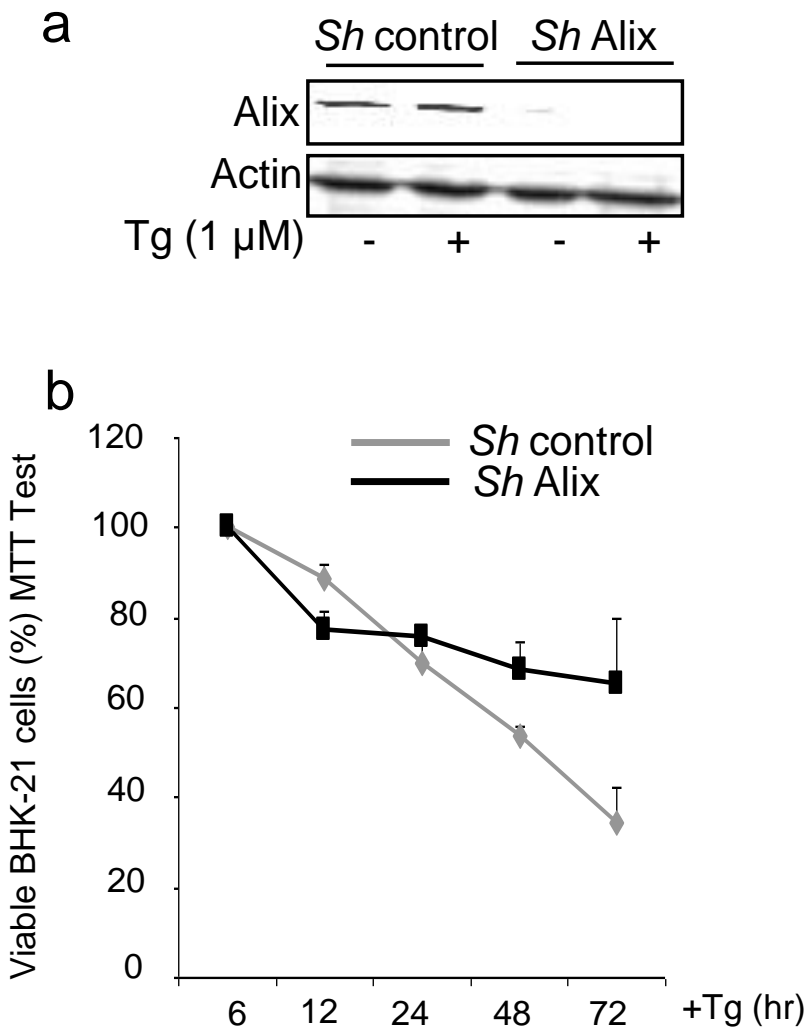
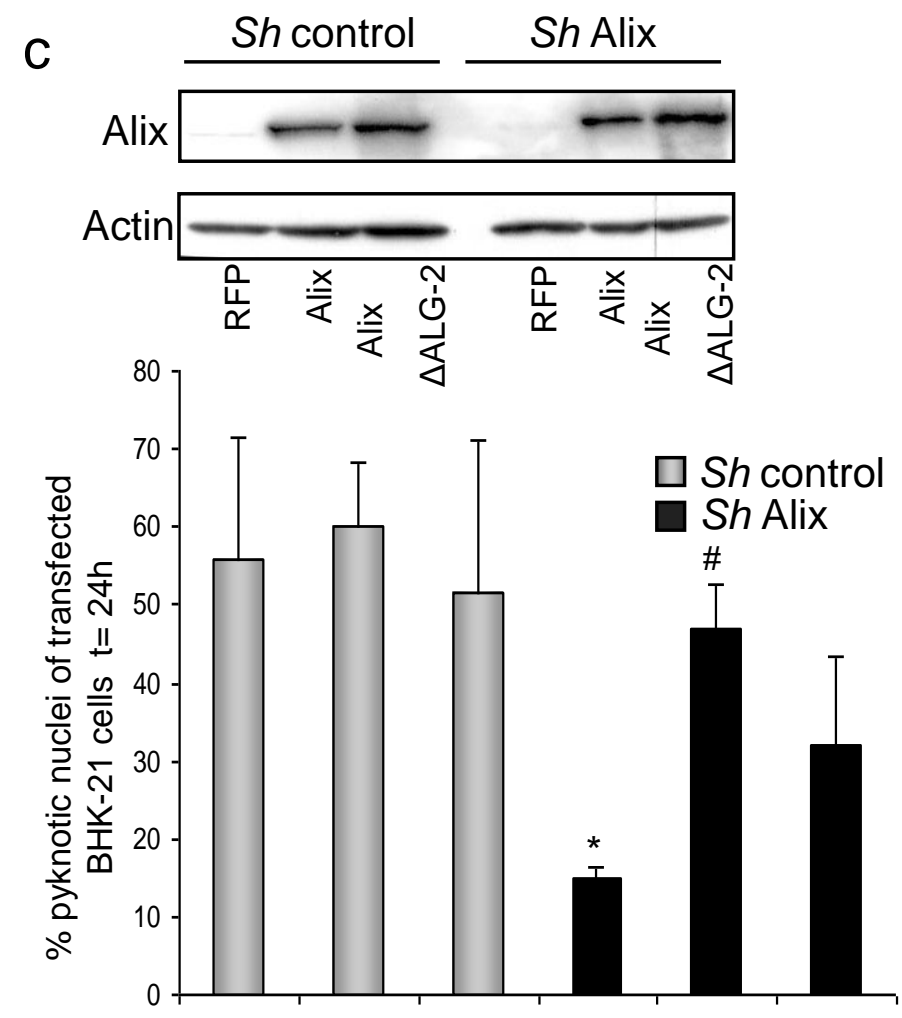

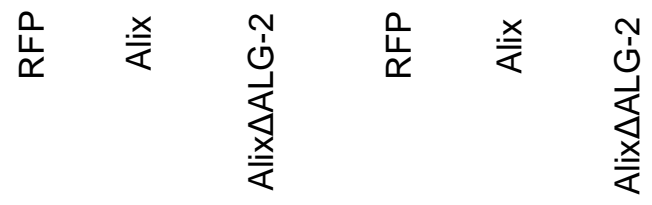

Figure 2 
Figure 3

a

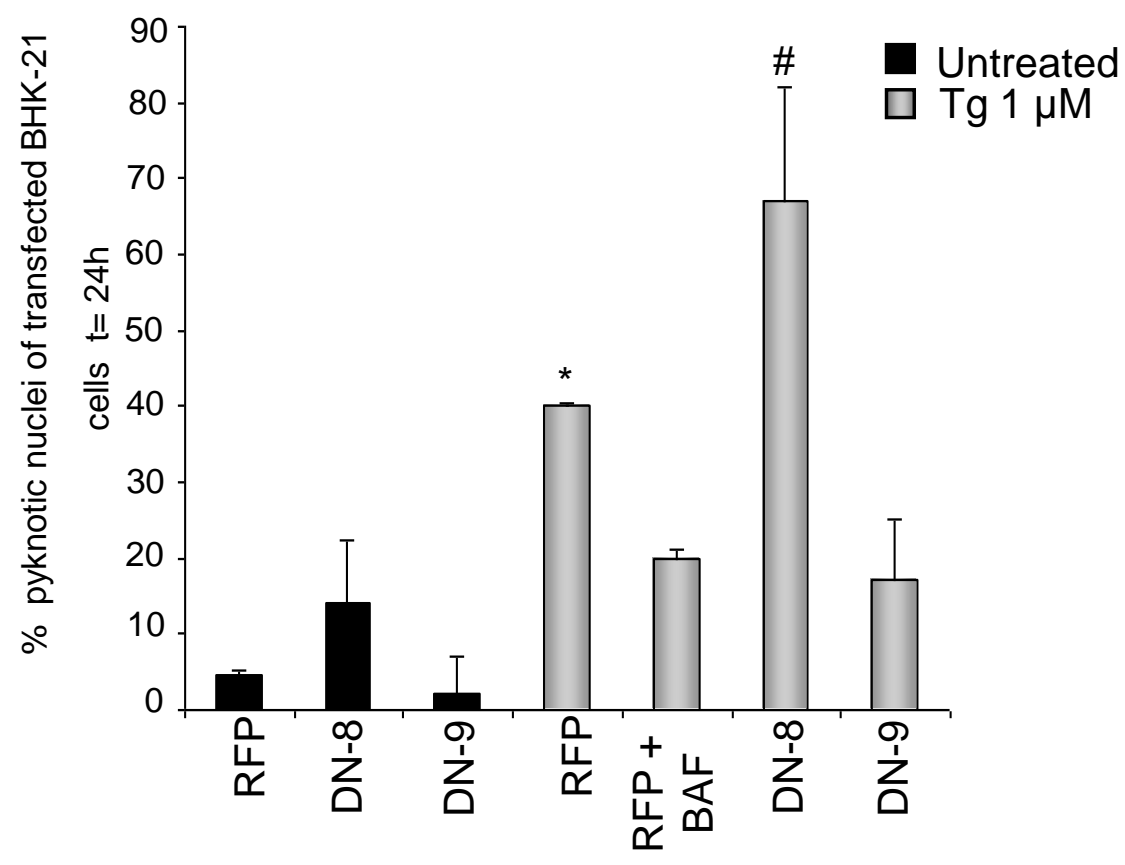

b

Sh Control

Sh Alix

activated caspase 9 nuclear staining

$-\operatorname{Tg}$
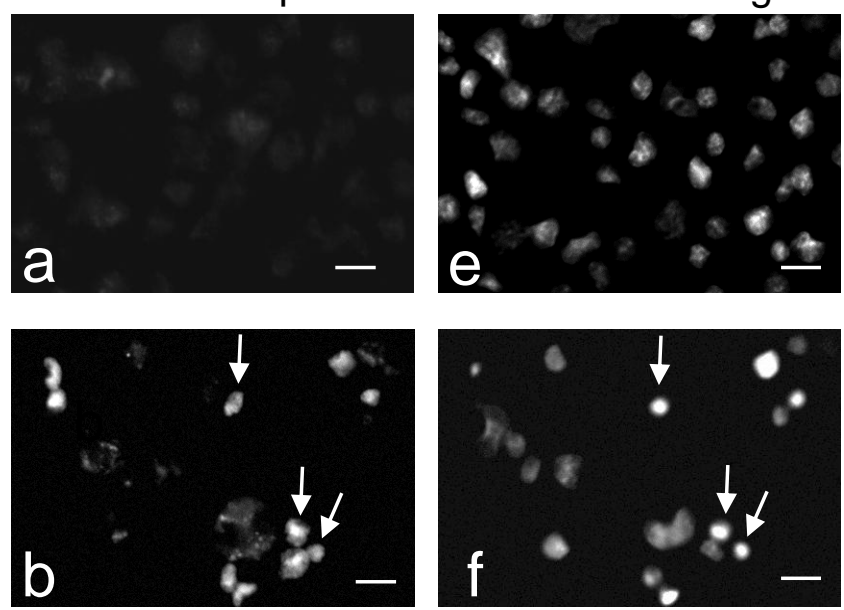
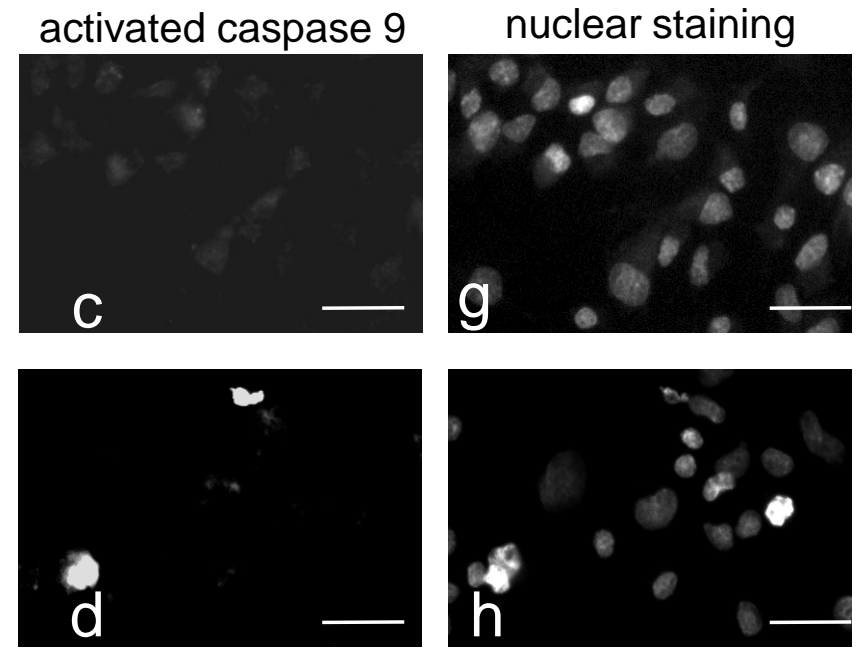

nuclear staining

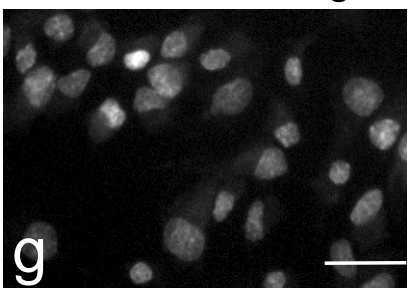

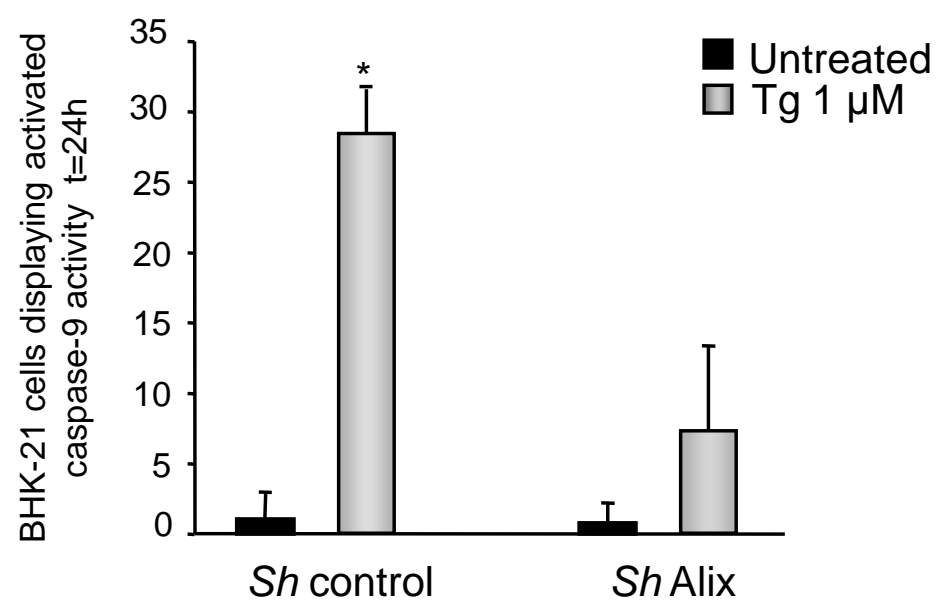

C

$+\mathrm{Tg}$

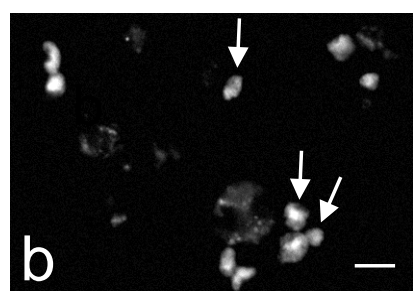

